\title{
Merging of Metacognitive Regulation Strategies and Activity Based Learning through Best Seller Mathematical Learning Activities to Enhance Student's Mastery of Mathematics
}

\author{
Mohamad Ariffin Abu Bakar*, Norulhuda Ismail \\ Faculty of Social Sciences and Humanities, School of Education, Universiti Teknologi Malaysia, Johor, Malaysia
}

Received July 9, 2019; Revised September 9, 2019; Accepted September 16, 2019

Copyright@2019 by authors, all rights reserved. Authors agree that this article remains permanently open access under the terms of the Creative Commons Attribution License 4.0 International License

\begin{abstract}
Metacognitive Regulation Strategies (MRS) and Activity Based-Learning (ABL) is a learning strategy that is significant and have proven to effect student's mastery. The student's ability to plan, monitor and evaluate the learning process and their thinking process, known as metacognitive regulation, can strengthen the understanding. ABL also has significant positive effects on students' level of interest, engagement and performance. Through the activity, students developed their communication skills, self-regulation and the learned knowledge has positive effects on retention due to learning by doing and having fun while learning. In fact, Best Seller Mathematical Learning Activities (Apm-BS) merges principles and strategies from the activity during learning and metacognitive regulation skills. This conceptual paper tries to discuss the potential of merging activity based learning and metacognitive regulation learning strategies as an intervention to the problem of mastering the mathematical concept of students. This activity was designed and created based on the basic of the concept of entrepreneurship, which involves buying and selling activities among students during the learning process. Students communicate and interact with peer to practice the metacognitive behavior and improve metacognitive skills in order to enhance their understanding.
\end{abstract}

Keywords Metacognitive Regulation Strategies, Metacognitive Regulation, Activity Based Learning, Mathematical Learning, Student's Mastery

\section{Introduction}

A mathematical thinker is an individual who is creative and innovative and is able to meet the demands of the 21st century. However, the constraints to fulfilling these goals are the problem of students to understand the mathematical concepts (Noor Hidayah \& Zanaton, 2017). The issue of poor mastery of concepts in mathematics is not to be underestimated and need immediate solutions in an effective way. So, what is needed is the cooperation of all stakeholders to act accordingly to overcome this problem. Students who do not master the mathematical concepts and do not understand the topics' need consider mathematical subjects as difficult and unpredictable (Du Toit \& Kotze,2009; Effandi \& Norhidayah, 2015; Nor Esah \& Nurulwahida, 2016; Aizu \& Hasbiah, 2017). In this regard, Syed Azman \& Siti Mistima (2017) argued that students would forget the mathematical concept and lost confidence when failing to solve mathematics questions.

Good metacognitive development, capabilities and practices are closely related to effective learning. While effective learning is influenced by activities during the learning process (Wan Hasmah \& Nur Munirah, 2015). Teacher practices play a role in improving students' metacognitive skills. Thus, the learning approach selected by the teacher should be in line with the student's metacognitive needs (Noor Hidayah \& Zanaton, 2017; Kyairaniah, Mohd Isa \& Maimun, 2017; Adnan \& Arsad, 2018). On this basis, the researcher sees the need for in-depth studies to see the relationship between conceptualization, metacognitive and appropriate learning activity factors. Perhaps this study can be used as a solution to solve mathematics performance problems especially in 
schools. It is hoped that the present study will contribute to the learning field in order to enhance student's mastery of the mathematics contents.

\section{Mastery of Mathematics among Students}

Mathematics is an abstract, using figures and symbols and requires thinking skills (Poh, 2000; Halim, 2011; Chris, 2015). According to Chris (2015) mathematics also includes logic, reasoning and critical thinking. That's why mathematics is considered difficult by some students (Noor Erma \& Leong, 2014; Du Toit \& Kotze,2009). Mathematics is also considered a killer subject and is not an interesting subject (Nurul Nashrah \& Effandi, 2017; Nor Ezah \& Nurulwahida, 2016). However, according to Noor Erma \& Leong (2014) there are still students who shows good achievement as well as those who remain in control of the mathematical concept despite being faced with easy topics. This is because, according to Harizon (2014), the way students understand the mathematical facts, realize the process, solve the problem and make generalization of the topic is through the student's own awareness of the learning process.

Besides that, the learning method also affects the awareness of learning process to master the concepts and math skills (Aizu \& Hasbiah, 2017). In that regard, the learning process should ensure that students can use the process of thinking and interaction skill. The students themselves need to be aware of their level of ability, which means that, they are knowing and aware of the potential of their thinking. Knowing the right and convenient way to learn, it may reduce the problem of mathematical learning. In this situation, the student's self-regulation about the thinking process and the action cause of that is the prediction of the learning process. The weakness of mathematical mastery among students is due to ignoring the metacognitive regulatory capacity that greatly influences the learning process of mathematics.

Metacognitive regulation is the highest component of metacognition other than metacognitive knowledge (awareness) and metacognitive experience (Du Toit \& Du Toit, 2013; Crawford, 2018). Through awareness and metacognitive experience, students will regulate their cognition to plan activities and thinking actions towards achieving learning goals (Crawford, 2018). If students can plan, control and evaluate their cognitive abilities in mathematical learning, the student can master the mathematical concept. Thus, its importance to mathematical teachers determines the best approaches so that aspects of metacognitive regulation can be improved. This is because real mathematical performance is determined by metacognitive regulation and not merely having knowledge or cognitive awareness.

\section{Metacognitive Regulation Strategies (MRS) and Activity Based Learning (ABL)}

Metacognitive regulation is a component of metacognition. There are three subcomponents, namely planning, monitoring, and evaluating. According to Do Toit \& Do Toit (2013) metacognitive regulation refers to the control of actions that students undertake in their learning process. Schraw \& Moshman (1995) states that these aspects are: i) planning ie planning, determining goals and studying resources and learning needs; ii) information management, which refers to the sequence and strategies used during learning among them to process information more efficiently, for example organizing, describing, summarizing or focusing; iii) monitoring of a own learning process or monitoring the use of learning strategies; iv) debugging is a method or strategy used to correct mistakes and weaknesses; and v) evaluation is a process or act of analyze the effectiveness of learning, finding, results, mastering or performance and evaluating strategy after learning experience.

The effectiveness of mathematical learning is strongly influenced by the effects of individual metacognitive regulation. According to Moos \& Ringdal (2012) this metacognitive regulation will spontaneously begin when a mathematical tasks is given by addressing the process to four phases. Understanding mathematical problems is the beginning of this cognitive process, at this stage metacognitive knowledge will play a role. However, subsequent metacognitive regulation will continue the cognitive process by setting goals, designing, selecting strategies, using strategies and then refocusing them with the evaluation phase. Obviously, metacognitive regulation plays many roles in ensuring students can solve problems or mathematical tasks.

Activity-based learning is a learning approach from the understanding of active learning theories and the development of constructivism philosophy. This activity learning approach was first introduced by David Horsburgh. For mathematical learning purposes, it is termed an Activity Based Teaching of Mathematics which involves students doing activities such as reading, writing, discussing, practical activities, problem-solving activities, analysis, synthesis and evaluation (Festus, 2013). According to Pokhrel (2018) the activities involved in this approach are like the use of materials, models, forms, charts, pictures, posters, games and experiments. In the context of learning, it is about what are doing, activities, situations and exercises with the aim of providing knowledge, skills and enhancing students' understanding. This activity will create conducive learning environment.

According to Nik Azis (1999) effective mathematical learning is in the form of a combination of diverse activities, and effectively and continuously interactions occur. For the purpose of applying and using the ABL 
approach to transform the mathematical learning of students, Bonwel \& Eison (2013) has outlined some features of ABL as a guide:

a. involves learning activities that enable students to develop their potentials and skills that are more than just listening to, not just receiving or transferring information

b. involves students in high-level thinking skills such us, analysis, synthesis and evaluation

c. are more likely to be exploring the attitudes and self-appraisal of the students

In relation, the $A B L$ principle also directs the development of metacognitive regulation through metacognitive learning strategies. According to Hasbullah (2015) activity is a mediator or tool that can be a moderator of metacognitive regulation. In addition, ABL also helps students learn independently and use their potential. In this context, Raudys (2018) describes ABL's impact on students' self-esteem as: i) students will remain focused on being active, ii) learning in new and different situations ie with full attention, emotion and more dynamic, iii) focusing on problem-solving and more critical.

The effectiveness of implementing strategies based on practically metacognitive skills is much discussed in studies that show increased student achievement. Among them are studies by Leidinger \& Perels (2012), Hasbullah (2015), Listiani, Wiarta \& Darsana (2014), Nongtodu \& Bhutia (2017), Cheng (2011), Shaw (2008), Su, Ricci \& Mnatsakanian (2016) Stephanou \& Mpiontini (2017) and Noorzeliana, Norazilawati \& Saniah (2015). Their positive results are clear that metacognitive greatly influences learning. Many researchers conclude that through metacognitive strategies, it can encourage the strengthening of knowledge in improving students' achievement.

Metacognitive skills can relate to the previous knowledge and form the new knowledge about mathematics, it reduces the nature of interconnectedness that exists due to the nature of the mathematical knowledge itself (Hasbullah,2015). Researchers also found that aspects of metacognitive regulation strongly influence students' performance, e.g aspects of monitoring, evaluating and following aspects of planning (Cheng,2011; Stephanou \& Mpiontini,2017). In addition, metacognitive skills can also develop problem-solving and thinking skills that will also have a direct impact on students' achievement. Students will be more careful in accuracy, perfection and self-determination in solving mathematical problems (Shaw,2008). The solution learned by the student will also enhance the thinking skills and give the impression that previous knowledge has been combined with new knowledge, applied and synthesized in a new form (Su, Ricci \& Mnatsakanian,2016).

Studies by Altintas \& Ozdemir (2012), Muhammad, Niaz, Maqsood, Faiza \& Sher Aman (2012), Hussain, Anwar \& Majoka (2011), Celik (2017), Khonchaiyaphum,
Srikunlaya \& Rakrai (2017) and Yuksel (2013) shows the ABL's impact on students' learning and have a positive impact on achievement. The researchers found that ABL's approach can increase the critical thinking skills and the attitudes of mathematical problem-solving also change (Altintas \& Ozdemir,2012). It can be concluded that in ABL, students are more motivated to think, criticize and ask questions. This activity can expose students to debates, collaborative learning, ideas, project creation, project presentation and positive attitude.

Therefore, in order to ensure learning process can improve the mastery of the students, the suitable and interactive activities should be provided. By involving and doing the activities, students can develop and train their metacognitive regulation skills that are seen to improve the self-regulation, to change their attitude towards learning positively and improve student's thinking skills. Thus, designing and developing learning activities in line with the needs of metacognitive regulation are required. In addition, further studies are also needed to relate the activity-based learning to satisfy the metacognitive regulation learning strategies.

\section{Conceptual Framework of Best Seller Mathematical Learning Activities (Apm-Bs)}

\subsection{Design Principles of Apm-BS}

The study was aimed at designing, implementing, and evaluating the effectiveness of learning activities through buying and selling simulations. Based on the Constructivist Theory, Vygotsky Social Development Theory and Metacognitive Theory, constructs are seen to influence students' learning. Constructivist theory states that learning is the process that students make modification of previous experience and knowledge in order to construct the new ones. Interactions, mediations, guidance and scaffolding become the important elements in Vygotsky's Theory to reflect the ability of the student in learning. While Metacognitive Theory proposes a metacognitive based learning strategy to optimize mental function in learning. So a conceptual framework can be built to see the relationship between the aspects or elements that will be the variables in this study.

Based on how the learning occur through the understanding of the theories, researchers design and develop an activity named Best Seller Mathematical Learning Activity (Apm-BS) with the 4P's McCarthy Marketing Model. So Apm-BS will be an independent variable in this study including the $4 \mathrm{P}$ elements that are related to products, prices, places and promotions in the activity. This $4 \mathrm{P}$ element will be contained in the phases of the activity to be designed. This apm-BS will be assessed to look at the students' mastery. Thus, the dependent variable 
in this study is the mastery of the student which will be an important measure of the effectiveness of the Apm-BS, while metacognitive regulation, including its components, planning, monitoring and evaluation will act as a moderate variable.

The present study is also a concept of intervention study. Apm-BS is a teaching method that implements treatment of conventional mathematical learning. The activities contained in them are expected to strengthen metacognitive regulations that encourage students to correctly solve mathematical problems. It is hoped that the mastery of the students can be enhanced through Apm-Bs activities.

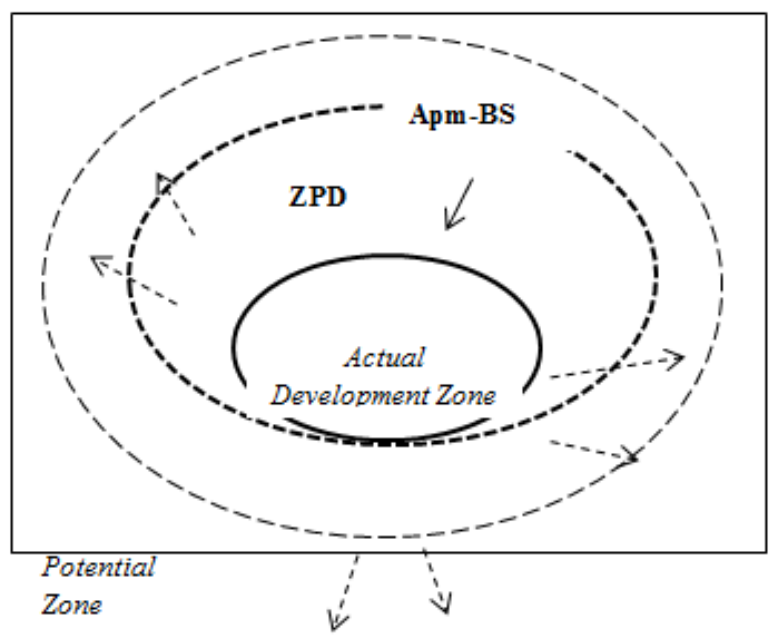

Source : Adapted from Tamil Selvan (2015) and Mcleod (2018)

Figure 1. Learning Concept of Apm-BS

\subsection{Implement of Apm-BS}

Since the design of this activity uses buying and selling as an intermediary of activities, there are some terms of the marketing used. In summary, in this activity the students will be divided into two groups namely 'seller' and 'customer' groups. The teacher is a 'banker' that controls the marketing process. In the context of learning, teachers are just as a provider of learning environment and will act as guiders and facilitators. The contents of the lesson refer to the 'product' which will be the source and learning materials. The 'product' is a mathematical question or specific task that needs to be solved. If the 'product' in the marketing world has a price, then in this activity the 'product' also has a certain price which is actually the level of difficulty according to Bloom's Taxonomy.

Then, a 'seller' group will plan a marketing strategy in the 'marketing planning' phase. The process of learning in this phase is actually a process during which a student solves mathematical problems, conducts operations and calculations in small groups cooperatively. The next phase is the process of buying and selling, which refers to the standard of promotional activities in marketing. 'Promotion time' will be the climax phase of learning activities and processes when students from the 'sellers' group sell, deliver explanations, explain, attract attention, or teach the 'customers' groups to understand mathematical concepts and solutions. During the 'promotion time', 'seller' applies peer tutoring and reciprocal teaching methods. Purchases will occur when the customer is satisfied with the explanation and understands the presentations. Next in the last phase of the activity, the calculations are made to determine the 'seller' that will be awarded of 'best seller'.

Table 1. The Apm-BS Related To Teaching And Learning Process

\begin{tabular}{|c|c|c|}
\hline $\begin{array}{c}\text { CHARACTER/ } \\
\text { ROLES }\end{array}$ & Apm-BS ACTIVITY & TEACHING AND LEARNING PROCESS \\
\hline $\begin{array}{l}\text { BANKER } \\
\text {-Teacher }\end{array}$ & - $\quad$ Financial control & $\begin{array}{ll}- & \text { Provides learning contents } \\
\text { - } & \text { Guiding students } \\
\text { - } & \text { Controlling time }\end{array}$ \\
\hline $\begin{array}{l}\text { SELLER } \\
\text {-Student }\end{array}$ & $\begin{array}{l}\text { Salesperson } \\
\text { Selling products }\end{array}$ & $\begin{array}{ll}- & \text { Teaching other students (presentation)-peer tutoring } \\
\text { - } & \text { Give relevant examples } \\
\text { - } & \text { Guiding }\end{array}$ \\
\hline $\begin{array}{l}\text { CUSTOMER } \\
\text {-Student }\end{array}$ & $\begin{array}{l}\text { As a customer } \\
\text { Buyer }\end{array}$ & $\begin{array}{ll}- & \text { Learner } \\
- & \text { Listening } \\
- & \text { Asking questions } \\
\end{array}$ \\
\hline PRODUCTS & Sales products & $\begin{array}{ll}- & \text { Learning content } \\
\text { - } & \text { Worksheet } \\
\text { - } & \text { Questions } \\
\end{array}$ \\
\hline $\begin{array}{l}\text { MARKETING } \\
\text { PLANNING }\end{array}$ & $\begin{array}{l}\text { The marketing strategy to be } \\
\text { determined by the salesperson }\end{array}$ & $\begin{array}{ll}- & 1 \text { or } 2 \text { students answer the questions cooperatively } \\
\text { - } & \text { Solve problems } \\
- & \text { Set up the presentation needs }\end{array}$ \\
\hline PROMOTION & $\begin{array}{ll}\text { - } & \text { Time to promote the product } \\
\text { - } & \text { Time to purchase }\end{array}$ & $\begin{array}{ll}- & \text { Presentations } \\
\text { - } & \text { Teaching and explant to others } \\
\text { - } & \text { Reciprocal Teaching } \\
\end{array}$ \\
\hline BEST SELLER'S TAG & Title to salesperson with highest sales & Reward to active students \\
\hline
\end{tabular}




\section{Merging of Activities and Metacognitive Regulation Strategies in Learning}

Basically, the development and design of these learning activities is an alternative approach and intervention of learning methods. Accordingly, the implementation of Apm-BS is based on the use of the instrument, which is a kit that contains hands-out consisting of a product, a sample of money and a 'best seller' tag. This interactive learning application in the form of offline technology is seen to be more flexible and facilitate teacher work. Basically, Apm-BS is a learning activity through a game of competition. Accordingly, the competition should have certain goals and targets to be achieved. In this activity, the goal can be seen from two points. The first is during the learning process, where the student must achieve victory in the competition. In the context of Apm-BS, the winner is to get the highest earning money that is directed to the student who plays as a salesperson. The title and "Best Seller" award will be given to the student. Second is, at the end of learning, the objective of learning. Master the concept, increase understanding, improve thinking skills and so on are the goals and objectives of learning. According to Hasbullah (2015) and Smith \& Mancy (2018) when learning activities require students to plan, set up the goals and targets, act on their planning strategies and constantly evaluate learning acquisitions, they relate to metacognitive regulation. This process can improve the students' thinking skills and potential.

It can be concluded that, through the implementation of activities, it have a positive effect on the students. Activities can be a medium for students to develop many aspects that will be an increasing factor of understanding. Through activities, according to Schraw \& Moshman (1995), Hasbullah (2015) and Nor Hidayah \& Zanaton (2017) can create skills in planning, monitoring and evaluating the learning process. The metacognitive skills can be enhanced through the self-regulation of students which also affects their attitudes and motivations. Previous experiences and active experiences during learning can be structured well through this activity. In addition, according to Pantiwati \& Husamah (2017) and Menz \& Cindy Xin (2016) activity can also be used as a tool for evaluating learning. This assessment process can occur independently i.e prologue (Menz \& Cindy Xin, 2016) or through interaction during activities (Pantiwati \& Husamah, 2017).

Applying this approach as a teaching and learning practice is essential to achieving effective learning goals. The features and principles of Apm-BS are also conceptualized by active learning and metacognitive development. Through activities, students will evaluate and look at something from the point of view, find similarities, evaluate causality, make predictions and estimates, not just memorizing and even be responsible for new experiences and knowledge (Raj, 2015). This coincides with the recommendation by Su, Ricci \& Mnatsakanian (2015) which proposes a strategy that allows students to think, regulate and coordinate their thinking to achieve mathematical learning outcomes.

When students are constantly exposed to cooperative or collaborative learning, they will communicate and interact with peers. Mathematical problem-solving becomes easier when they are guided by individuals with higher skill levels. Intellectual abilities will increase when students master the new concepts and skills, this will directly expand the current knowledge zone to the zone with high potential such as improvements in critical thinking skills (Taylor, 1992). This process will repeat in the next learning and can increase the mastery of the mathematical concept of the students.

\section{Conclusions}

The change in students' learning style illustrated in this study is due to excite, motivated and fun through the learning activities. Mastery can also be improved as students undergo self-regulation, and change learning strategies to continuously explore knowledge (Farah \& Che Nidzam, 2014). These situation shows the development of metacognitive skills has done. Being active and guided is the effect of planning, exploring and interacting is the effect of monitoring component, while the evaluation component can be seen when self-determination or self-concept will strengthen the students' understanding.

\section{REFERENCES}

[1] Abdul Halim Abdullah (2011). Guna Cara Kreatif Tarik Minat Pelajar.Ruangan Surat, Berita Harian,25.06.2011 (Sabtu). Berita Harian Press.

[2] Ackerman, R.\& Goldsmith, M. (2011). Metacognitive Regulation of Text Learning: On Screen Versus on Paper. Journal of Experimental Psychology: Applied.Vol. 17, No. 1, 18-32. Doi : 10.1037/a0022086.

[3] Adnan \& Arsad Bahri (2018). Beyond effective teaching: Enhancing students' metacognitive skill through guided inquiry. IOP Publishing .Journal of Physics: Conf. Series 954 (2018) 012022 doi :10.1088/1742-6596/954/1/012022.

[4] Altintas,E \& Ozdemir, A. S.(2012). The Effect Of Teaching With The Mathematics Activity Based On Purdue Model On Critical Thinking Skills And Mathematics Problem Solving Attitudes Of Gifted And Non-Gifted Students. Procedia - Social and Behavioral Sciences 46 ( 2012 ) 853 857.

[5] Aizu Khalili Zohedi, Nor Hasbiah Ubaidullah \& Norasikin Fabil (2017). Aplikasi Prinsip Animasi Exaggeration, Kemahiran Berfikir Kritis dan Kreatif serta Model Motivasi ARCS Terhadap Topik Integer Matematik Tingkatan Satu. Journal of ICT in Education (JICTIE) ISSN 2289-7844 / 


\section{Vol. 4 / 2017 / 52-65}

[6] Bonwell, C. C., Eison, J. A.(1991).Active Learning: Creating Excitement In The Classroom. ERIC Digest. ERIC Clearinghouse on Higher Education. Washington DC.

[7] Chekwa, E., McFadden, M., Divine, A. \& Dorius, T.(2015). Metacognition: Transforming the Learning Experience. Journal of Learning in Higher Education. Spring 2015 (Volume 11 Issue 1) p109-112.

[8] Cheng, E .C. K. (2011). The Role of Self-regulated Learning in Enhancing Learning Performance. The International Journal of Research and Review. Volume 6 Issue 1, March 2011.

[9] Celik, H. C.(2018).The Effects of Activity Based Learning on Sixth Grade Students' Achievement and Attitudes towards Mathematics Activities. EURASIA Journal of Mathematics, Science and Technology Education, 2018, 14(5), 1963-1977.

[10] Chris, O.(2015).Teaching Maths In The 21st Century. Changing The Focus From Calculations To Critical Thinking. Retrieved from: http://blog.learningbird.com.

[11] Conley, D. (2014).Learning strategies as metacognitive factors: A critical review. Educational Policy Improvement Center. Eugene, Oregon.

[12] Crawford, C. (2018). What Metacognition Looks Like In The Primary Classroom: A 7-Step Practical Approach To Maths Teaching. Retrieved from:https://thirdspacelearning. com/blog/7-steps-eef-metacognition-primary-classroom-m aths/

[13] Du Toit, SD. \& Du Toit, GF. (2013).Learner metacognition and mathematics achievement during problem-solving in a mathematics classroom .TD The Journal for Transdisciplinary Research in Southern Africa, 9(3), Special edition, December 2013, pp. 505-518.

[14] Du Toit, S. \& Kotze, G.(2009). Metacognitive Strategies in the Teaching and Learning of Mathematics. Pythagoras.70, 57-67.

[15] Emeny, W.(2013). Metacognition. Thoughts On Teaching Mathematical Problem Solving Skills. Retrieved from: http://www.greatmathsteachingideas.com/2013/07/23/meta cognition-thoughts-on-teaching-mathematical-problem-sol ving-skills/

[16] Farah Aida Sanip \& Che Nidzam Che Ahmad (2014). Kesedaran Strategi Metakognitif dan Kemahiran Berfikir Aras Tinggi (KBAT) Dalam Kalangan Pelajar Biologi .Jurnal Penyelidikan Pendidikan (KPM) Jilid 15, 2014.

[17] Fazal ur Rahman, Nabi Bux Jumani, Muhammad Ajmal Chaudry, Saeed ul Hasan Chisti, \& Fahim Abbasi (2010). Impact of Metacognitive Awareness On Performance Of Students In Chemistry. Contemporary Issues In Education Research.Vo 3, No10.

[18] Festus, A. B.(213).Activity -Based Learning Strategies in the Mathematics Classrooms. Journal of Education and Practice.Issn:2222-1735.Vol.4, No.13.

[19] Gartmann, S. \& Freiberg, M.(1998).Metacognition and Mathematical Problem Solving: Helping Students to Ask The Right Questions. The Mathematics Educator. Volume 6
Number 1.

[20] Harizon Binti Suffian (2014). Amalan Pemilihan Dan Penggunaan Contoh Guru Matematik Sekolah Rendah: Kajian Kes. Laporan Tesis PHD. Universiti Pendidikan Sultan Idris.

[21] Hasbullah (2015). The Effect Of Ideal Metacognitif Strategy on Achievement In Mathematic. International Journal of Educational Research and Technology.6[4] 2015; 42-45. DOI: 10.15515/ijert.0976-4089.6.4.4245

[22] Hussain, S., Anwar, S. \& Majoka, M. I. (2011). Effect Of Peer Group Activity-Based Learning On Students' Academic Achievement In Physics At Secondary Level. International Journal Of Academic Research. Vol. 3. No.1. January, 2011, Part III.

[23] Kaune, C. (2006). Reflection and Metacognition in Mathematics Education -Tools for the Improvement of Teaching Quality. ZDM 2006 Vol. 38 (4).

[24] Khonchaiyaphum, P., Srikunlaya, S. \& Rakrai, W.(2017). Development Of Activity-Based Learning Conceptual Approach With The Stem Education Instructional Method On The Photosynthesis Issue At The 11th Grade Level To Promote Students' Learning Achievements And Their Systematic Thinking Abilities. European Journal of Education Studies. Volume 3, Issue 6,2017.

[25] Kyairaniah Abu Hassan, Mohd Isa Hamzah \& Maimun Aqsha Lubis (2017). Tahap Kemahiran Metakognitif Murid Sekolah Menengah Di Kawasan Felda Dalam Pembelajaran Pendidikan Islam. ASEAN Comparative Education Research Journal on Islam and Civilization (ACER-J) Volume 1(1) January 2017, 94-106.

[26] Laistner, N.(2016).Metacognition and Student Achievement in Mathematics. Education and Human Development. 611. Retrieved from: http://digitalcommons.brockport.edu/ehd_ theses/611

[27] Leidinger, M. \& Perels, F.(2012). Training Self-Regulated Learning in the Classroom: Development and Evaluation of LearningMaterials to Train Self-Regulated Learning during RegularMathematics Lessons at Primary School. Hindawi Publishing Corporation Education Research International Volume 2012, Article ID 735790. Doi:10.1155/2012/735790.

[28] Listiani, N. W, Wiarta, I. W. \& Darsana, I. W. (2014). Penerapan Model Pembelajaran Metakognitif Berbasis Masalah Terbuka Berpengaruh Terhadap Hasil Belajar Matematika Siswa Kelas V Sd Gugus 8 Blahbatuh. Jurnal Mimbar PGSD Universitas Pendidikan Ganesha. Vol: 2 No: 1,2014 .

[29] McLeod, S. A. (2018, Aug 05). Lev Vygotsky. Retrieved from: https://www.simplypsychology.org/vygotsky.html

[30] McMahon, M. \& Oliver, R. (2003).Teaching Metacognitive Regulation Of Reading Comprehension In An On-Line Environment. In D. Lassner \& C. McNaught (Eds.), Proceedings of World Conference on Educational Multimedia, Hypermedia and Telecommunications.(pp. 2464-2471). Chesapeake, VA: AACE.

[31] Menz, P. \& Cindy Xin (2016).Making Students' Metacognitive Knowledge Visible through Reflective Writing in a Mathematics-for-Teachers Course. Collected Essays on Learning and Teaching, Vol. IX. Simon Fraser 
University.

[32] Moos, D. C. \& Ringdal, A. (2012). Self-Regulated Learning in the Classroom: A Literature Review on the Teacher's Role. Education Research International. Volume 2012, Article ID 423284, 15 pages.Doi:10.1155/2012/423284.

[33] Muhammad Khan, Niaz Muhammad, Maqsood Ahmed, Faiza Saeed \& Sher Aman Khan.(2012). Impact Of Activity-Based Teaching On Students' Academic Achievements In Physics At Secondary Level. Academic Research International. Vol. 3, No. 1, July 2012.

[34] Nongtodu, S. \& Bhutia, Y.(2017).Metacognition and its relation with academic achievement among college going students of Meghalaya. International Journal of Education and Psychological Research (IJEPR). Volume 6, Issue 2, June 2017.

[35] Noor Hidayah binti Ibrahim \& Zanaton H.Iksan (2017). Strategi Metakognitif dan Kemahiran Berfikir Aras Tinggi Dalam Proses Pengajaran dan Pembelajaran. Simposium Pendidikan diPeribadikan: Perspektif Risalah An-Nur (SPRiN2017).

[36] Noorzeliana Idris, Norazilawati Abdullah \& Saniah Sembak (2015). Kesedaran Metakognisi Dan Pemahaman Konsep Dalam Penyelesaian Masalah Matematik. Jurnal Pendidikan Sains \& Matematik Malaysia Vol.5 NO.2 DEC 2015 / ISSN 2232-0393

[37] Noor Erma Binti Abu \& Leong Kwan Eu (2014).Hubungan Antara Sikap,Minat,Pengajaran Guru Dan Pengaruh Rakan Sebaya Terhadap Pencapaian Matematik Tambahan Tingkatan 4. Jurnal Kurikulum \& Pengajaran Asia Pasifik. Januari 2014, Bil. 2 Isu 1

[38] Nor Ezah Binti Ariffin \& Nurulwahida Binti Hj. Azid @ Aziz (2016). Persepsi Murid Tahun Lima Terhadap Penggunaan Kaedah Model Bar Dalam Penyelesaian Masalah Matematik Berayat Tajuk Pecahan. International Seminar on Generating Knowledge Through Research, UUM-UMSIDA, 25-27 October 2016, Universiti Utara Malaysia, Malaysia. Retrieved from: http://ojs.umsida.ac.id/index.php/icecrs

[39] Nik Azis Nik Pa (1999).Pendekatan Konstruktivisme Radikal Dalam Pendidikan Matematik. Penerbit Universiti Malaya.Kuala Lumpur.

[40] Pantiwati, Y. \& Husamah (2017). Self and Peer Assessments in Active Learning Model to Increase Metacognitive Awareness and Cognitive Abilities. International Journal of Instruction. 10(4), 185-202. Retrieved from : https://doi.org/10.12973/iji.2017.10411a

[41] Pokhrel, T. R. (2018).Activity Based Mathematics Instruction: Experiences in Addressing the 21st-Century Skills. Journal of Mathematics Education. Vol. 11, No. 1, pp. 46-61. March 2018.

[42] Poh Swee Hiang (2000). Siri Pendidikan Perguruan, Pedagogi Sains 2:Strategi Pengajaran Pembelajaran Sains. Kumpulan Budiman Sdn. Bhd. Subang Jaya, Selangor.

[43] Raj,M.B.(2015).The Effectiveness of Activity Based Learning: An Analysis. Veda's Journal of English Language and Literature- JOELL, 2(4), 84-87.

[44] Shaw, S. C.(2008). The Effects Of Metacognitive Awareness On The Development Of Mathematical
Problem-Solving Skills In Fourth-Grade Homework Assignments. Education and Educational Psychology. Retrieved from : http://repository.wcsu.edu/educationdis/8.

[45] Schneider, W. \& Artelt, C.(2010). Metacognition And Mathematics Education. ZDM Mathematics Education (2010) 42:149-161. Doi: 10.1007/s11858-010-0240-2.

[46] Schraw, G. \& Moshman, D. (1995) .Metacognitive Theories. Educational Psychology Review 7:4 (1995), pp. 351371.Online :http://digitalcommons.unl.edu/edpsychpapers/ 40

[47] Smith, J.M \& Mancy, R. (2018) Exploring The Relationship Between Metacognitive And Collaborative Talk During Group Mathematical Problem Solving-What Do We Mean By Collaborative Metacognition?. Research in Mathematics Education, 20:1, 14-36,DOI:10.1080/14794802.2017.1410 215.

[48] Sperling, R. A., Howard, B. C., Miller, L. A. \& Murphy, C.(2002).Measures of Children's Knowledge and Regulation of Cognition. Contemporary Educational Psychology. 27, 51-79 (2002) Doi:10.1006/ceps.2001.1091.

[49] Stanton, J. D., Neider, X. N., Gallegos, I. J. \& Clark, N. C. (2015). Differences in Metacognitive Regulation in Introductory Biology Students: When Prompts Are Not Enough. CBE-Life Sciences Education. Vol. 14, 1-12, Summer 2015. Doi : 10.1187/cbe.14-08-0135

[50] Stephanou, G., \& Mpiontini,M.(2017).Metacognitive Knowledge and Metacognitive Regulation in Self-Regulatory Learning Style, and in Its Effects on Performance Expectation and Subsequent Performance across Diverse School Subjects. Psychology, 8, 1941-1975.https://doi.org/10.4236/psych.2017.812125.

[51] Su, H. F., Ricci, F. A., \& Mnatsakanian, M. (2016). Mathematical teaching strategies: Pathways to critical thinking and metacognition. Journal of Research in Education and Science (IJRES), 2 (1), 190-200.

[52] Tanner, K. D. (2012).Promoting Student Metacognition. CBE-Life Sciences Education. Vol. 11, 113-120, Summer 2012. Doi: 10.1187/cbe.12-03-0033.

[53] Tamil Selvan A/L Subramaniam (2015). Pembangunan Dan Penilaian Perisian E-PBL ReC Untuk Kursus Kejuruteraan. Laporan Tesis PHD. Fakulti Pendidikan, Universiti Kebangsaan Malaysia.

[54] Taylor, L. (1992).Mathematical Attitude Development From A Vygotskian Perspective. Mathematics Education Research Journal. Vol. 4, No.3.

[55] Tzohar-Rosen, M. \& Kramarski, B. (2014).Metacognition, motivation and emotions: Contribution of self-regulated learning to solving mathematical problems. Global Education Review.1 (4). 76-95.

[56] Wan Hasmah \& Nur Munirah (2015). Siri Kaedah Pengajaran dan Pembelajaran. :Permainan dan Simulasi. Dewan Bahasa dan Pustaka (DBP).Kuala Lumpur.

[57] Wan Hasmah \& Nur Munirah (2015).Siri Kaedah Pengajaran dan Pembelajaran: Pembelajaran Aktif. Dewan Bahasa dan Pustaka (DBP).Kuala Lumpur. 